\title{
ビデオシンポジウム 気管食道科領域における鏡視下手術·96
}

\section{甲状腺癌の気道浸潤例に対するコラーゲン人工気管の再建}

\author{
淮田哲昭，大谷 尚志，門倉 義幸
}

コラーゲン人工気管を開発し，気管の再建を 行っている。この方法はコラーゲン板の人工気 管が結合織に置換されて組織化し，管腔を形成 するもので内腔面は線毛円柱上皮の再生により 被覆されるものである。

患者は頸部気管が大幅に切除されても約 6 力 月〜 1 年程度で気切孔を閉鎖し, 通常の鼻呼吸 と発声が可能となるものである。

今回供覧する症例は 80 歳, 女性, 約 $2 \sim 3$ 力 月前より血痰, 喘鳴, 夜間の呼吸苦が出現して 来院した。15年前に他病院にて甲状腺乳頭癌に て甲状腺右葉切除を行って抢り，その再発腫場 が輪状軟骨を中心に上下に気道内へ侵入してい るものと判明した。

右頸部郭清術とともに腫瘍部の喉頭気管を切 除した。気道の切除範囲は甲状軟骨右側下 $1 / 3$, 輪状軟骨右側 $1 / 2$ 周, 気管第 $1 \sim 5$ 輪の $2 / 3$ 周で あった。また右側の反回神経はすでに麻痺して いた。

コラーゲン板は牛皮コラーゲンより得られた 八イドコラーゲンで hexamethylisocianate で 架橋を入れることによって内腔を保つ硬度とな つている。残存気管との縫合にあたってはコラ ーゲン内腔面に気管粘膜が overlap するよう にし，結合織に置換された気管壁を線毛円柱上 皮が被覆する。

本法の特徴は以下のごとくである。全くの biomaterial で異物として存在しなくなる。内 腔面は線毛円柱上皮で被われ, 疢の喀出に支障 はないこと。一次的再建ができ, 他の再建法と 比べ手術侵襲や合併症が少なく，また軟骨など 他部より採取する必要がないこと。

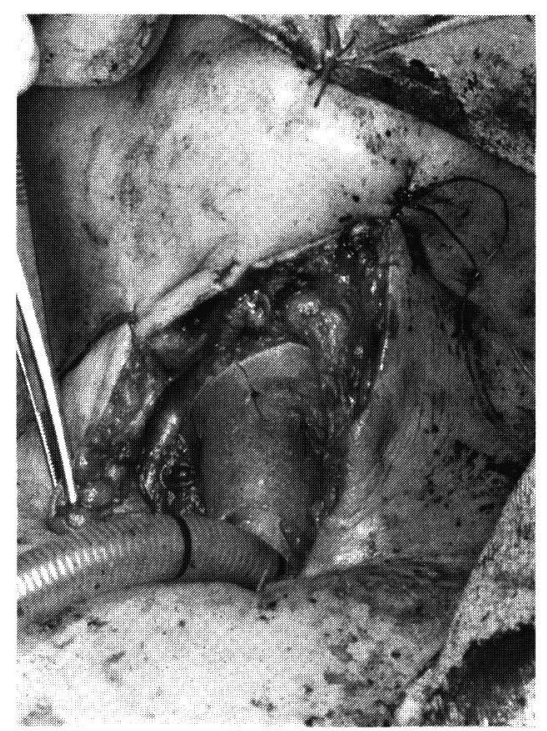

図 1 再建気管

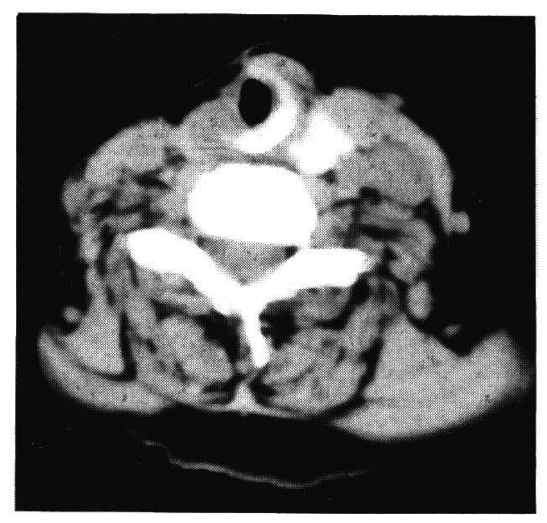

図 2 術後の CT（輪状軟骨部）

昭和大学藤が丘病院耳鼻咽喉科 